\title{
A Citizen - Centric Integrated Information System Roadmap for Municipalities
}

\author{
Meltem Ozturan \\ Dept. of Management Information Systems, Bogazici University \\ Bebek 34342, Istanbul, Turkey \\ E-mail: meltem.ozturan@boun.edu.tr \\ Serkan Alacam \\ Dept. of Management Information Systems, Bogazici University \\ Bebek 34342, Istanbul, Turkey \\ E-mail: serkan.alacam@boun.edu.tr
}

Abide Coskun-Setirek (Corresponding author)

Dept. of Management Information Systems, Bogazici University

Bebek 34342, Istanbul, Turkey

E-mail: abide.coskun@boun.edu.tr

Tugrul Cabir Hakyemez

Dept. of Management Information Systems, Bogazici University

Bebek 34342, Istanbul, Turkey

E-mail: thakyemez@sakarya.edu.tr

\section{Hanife Kebapci}

Dept. of Management Information Systems, Bogazici University

Bebek 34342, Istanbul, Turkey

E-mail: hanifekebabci@hotmail.com 
Elif Ozturk

Dept. of Management Information Systems, Bogazici University

Bebek 34342, Istanbul, Turkey

E-mail: elifozturk1980@ hotmail.com

Ersan Tasan

Dept. of Management Information Systems, Bogazici University

Bebek 34342, Istanbul, Turkey

E-mail: ersantasan@gmail.com

Received: Nov. 2, 2017 Accepted: Nov. 16, 2017 Online published: Nov. 20, 2017

doi:10.5296/jpag.v7i4.12093 URL: https://doi.org/10.5296/jpag.v7i4.12093

\begin{abstract}
The purpose of the study is to analyze e-government implementation and effectiveness at the municipal level in the vision of information system (IS) integration and to propose a roadmap for an integrated information system (IIS) for municipalities from the citizens' perspective. Integration models proposed in the literature are reviewed and merged into a more comprehensive model. Based on the proposed model, integration process occurs under four domains: strategic, organizational, logical and physical. Related approaches of hierarchy, structure, direction and extent are analyzed and evaluated for each domain. Then, IS practices for seven different municipalities are examined and compared to each other so as to evaluate the current situation. At the final stage, a practical structural framework is developed and presented. As a result of the longitudinal interviews with Saryyer Municipality, the general framework and a roadmap for municipalities are put forward. While this roadmap can be extended further by other researchers, it can also act as a base for practitioners to develop integrated information systems (IIS) for citizen services offered local governments.
\end{abstract}

Keywords: integrated information systems, e-municipality, e-government

\title{
1. Introduction
}

Globalization and technological evolution forces organizations to respond to rapid changes in order to sustain their market position. Organizations can manage to cope with these changes only with business components that work together in harmony. This harmony can be achieved by coordination of all business functions both in internal and external environment which ends up as integration of information systems (IS). The main aim of IS integration is to respond to dynamic challenges in the markets is by providing information consistency 
throughout the organization (Bhatt and Troutt, 2005).

Integrated information systems (IIS) is the composition of data collection, process, and dissemination, and physical or formal linkage of IS and subsystems (Wyse and Higgins, 1993). IS integration is an obstacle to many businesses in existence of independent systems that have not been designed to communicate with each other (Themistocleous et al., 2004). Information needs and future requirements of a business cannot be handled efficiently due to this lack of compatibility between these systems (Bhatt and Troutt, 2005).

Integration projects can be successful with only a good roadmap strategy. Researchers offered different integration frameworks throughout the literature which concludes with broad dimensions. One dimension is the domain that defines where the integration occurs like strategic, tactical and operational site; another dimension is the approach that defines the direction of integration like horizontal or vertical; third dimension is the degree of integration that defines the strictness of unification like tight or loose; and last dimension is the level that conceptualize overall integration like distributed, independent or connectable.

In this context, integration issues are examined for various organizations in literature. Municipality, which is one of these organizations, highly needs to coordinate business processes and share information between stakeholders due to its service oriented operations. Quality of public service delivery to citizens and improvement in internal managerial efficiency are challenges for municipalities that impose them invest on innovation. E-government is introduced in the late 1990s and is one of the interesting concepts in the field of public administration in the late 1990s (Moon, 2002), and is defined as "the production and delivery of government services through information technology (IT) applications" (Moon, 2002). Almarabeh and AbuAli (2010) defines the concept more broadly as; "government use of information communication technologies to offer for citizens and businesses the opportunity to interact and conduct business with government by using different electronic media such as telephone touch pad, fax, smart cards, self-service kiosks, e-mail / Internet, and electronic data interchange".

The aim of the study is to analyze e-government implementation and effectiveness at the municipal level in the vision of IS integration. The article will explore different perspectives of integration of IS throughout a conceptual framework, will make comparison of seven successful municipalities in different parts of Turkey, and will propose a roadmap for an efficient integrated IS from citizen services point of view for municipalities. Recommendations will be made according to success criteria measures for each domain.

\section{Literature Review}

\subsection{Background on Integrated Information System Issues}

Since cases of integration of different IS are unique processes which require specific models and implementation strategies, there exists numerous studies in the literature proposing different perspectives which are named as dimensions in this study. At this point, reconciling different methods and attitudes would be highly useful since this might allow finding fundamental requirements of any IS integration project regardless of size and area. 
In the literature, different integration frameworks conclude with broad dimensions which are domains, approaches, degrees, and levels. They are named as domains in this study. Proposed different attitudes and methods of distinct studies are named as approaches of integration. While the strictness of integration for distinct domains is named as degrees of integration, the overall measure of integration for the project is called levels of integration.

\subsubsection{Integration Domains}

Domains are fundamental layers that determine the areas of interoperability in an information system. Although different classifications and naming conventions exist in the literature, interoperability domain terms proposed by different authors can be gathered based on their similarities as given in Table 1 .

Table 1. Information system integration domains proposed in the literature

\begin{tabular}{ll}
\hline Integration Domains & Author(s) \\
\hline Business, Application, Physical & Panetto \& Cecil (2013), Izza (2009) \\
$\begin{array}{l}\text { Strategic, Organizational, Logical, Physical } \\
\text { Organizational, Semantic, Syntactic, Technical }\end{array}$ & Madnick \& Wang (1988) \\
$\begin{array}{l}\text { Business, Knowledge, Application, Data, } \\
\text { Communication }\end{array}$ & Chen et al. (2010) \\
Strategic, Tactical, Operational & Bernardo et al. (2008), Asif et al. (2009) \\
Business, Processes, Services, Data & Jørgensen (2008) \\
Organizational, Semantic, Technical & Chen et al. (2008) \\
Business, Organizational, Processes, & Chen et al. (2008) \\
Information technology & Henderson \& Venkatraman (1993) \\
Community, Administration, Service, & Pankowska (2008) \\
Technology & \\
Social, Functional, Structural & Peterson (2000) \\
\hline
\end{tabular}

The domains might be grouped into four basic categories of interoperability: strategic, organizational, and logical (semantic or tactical), and physical (technical) integration as proposed by Madnick and Wang (1988). Integration process typically targets at ultimate and unified integration for which strategic and business oriented integration should be reached. Organizational barriers should be overcome before reaching this level of interoperability, which in itself requires that semantic operations and services on the data are integrated. Before all this operation is achieved however, the process begins with physical connection among constituents of the system. The literature agrees on such layered, hierarchical integration consisting of separate domains. Models suggested by different studies and various terminologies proposed might be matched and structured to express same or similar meanings based on Madnick and Wang's research as in Table 2. 
Table 2. Layered integration domains

\begin{tabular}{|c|c|c|c|c|}
\hline \multicolumn{5}{|c|}{ Integration Domains } \\
\hline Strategic & Organizational & Logical & \multicolumn{2}{|c|}{ Physical } \\
\hline \multicolumn{2}{|c|}{ Business } & \multirow{2}{*}{$\frac{\text { Application }}{\text { Semantic }}$} & \multicolumn{2}{|c|}{ Physical } \\
\hline & Organizational & & Syntactic & Technical \\
\hline \multicolumn{2}{|c|}{ Business } & \begin{tabular}{l|l} 
Knowledge & Application \\
\end{tabular} & Data & Communication \\
\hline \multicolumn{2}{|c|}{ Strategic } & Tactical & \multicolumn{2}{|c|}{ Operational } \\
\hline \multicolumn{2}{|c|}{ Business } & Processes & Data & \\
\hline & Organizational & Semantic & \multicolumn{2}{|c|}{ Technical } \\
\hline $\begin{array}{l}\text { Business } \\
\text { strategy }\end{array}$ & $\begin{array}{l}\text { Organizational } \\
\text { structure }\end{array}$ & Processes & \multicolumn{2}{|c|}{$\begin{array}{l}\text { Information technology } \\
\text { strategy }\end{array}$} \\
\hline \multicolumn{2}{|c|}{ Strategic integration } & Process integration & \multicolumn{2}{|c|}{ System integration } \\
\hline $\begin{array}{c}\text { Community } \\
\text { level }\end{array}$ & $\begin{array}{c}\text { Administration } \\
\text { level }\end{array}$ & Service level & \multicolumn{2}{|c|}{ Technology level } \\
\hline \multicolumn{2}{|c|}{ Social } & Functional & \multicolumn{2}{|c|}{ Structural } \\
\hline
\end{tabular}

\subsubsection{Integration Approaches}

Approaches are unique attitudes towards integration process in the literature. Every approach examines and handles integration with a different side. For instance centralized-decentralized and comprehensive-selective duality determines structure of integration and if integration aims at one unified centralized structure or not. Horizontal-vertical approach is about direction of integration or area of focus: hierarchical interoperability (horizontal) or distinct processes (vertical). Internal-external integration approach focuses on extent of the integration process. Internal integration is an act of a singular entity whereas external integration includes two similar entities (e.g. companies or municipalities) that target. Top-down/bottom-up approaches differ according to the origin of initiative. They define hierarchy of integration. In top down integration the administration implements changes whereas in bottom up integration a need arises among lower units or workers. Different approaches observed in the literature are summarized in Table 3.

\subsubsection{Degree of Integration}

Degrees of integration express how close the parties are integrated to each other in terms of their IS. Depending on the context of the integration, the researchers name the classes in different ways. Some researchers classify the degrees as "total integration-partial integration-no integration" where others prefer to call the classes "partial integration-full integration". Also "tight integration-loose integration", "complete-sparse" and "harmonization, cooperation and amalgamation" terms have been used by other researches as well to classify the degree of integration. The authors and their proposed degrees of integration are summarized in Table 4. 
Table 3. Information system integration approaches proposed in the literature

\begin{tabular}{l|l}
\hline Integration Approaches & Author(s) \\
\hline Horizontal vs. Vertical & Layne and Lee (2001) \\
& Gillies et al. (1993) \\
\hline Centralized vs. Decentralized & Heeks (1999) \\
(hybrid/core-periphery/federal) & Peterson et al. (2000) \\
& Evgeniou (2002) \\
& Hugoson (2007) \\
& Bekkers (2009) \\
& Shea and Garson (2010) \\
\hline Internal vs. External & Platts (1995) \\
& Peterson (2004) \\
& Maiga et al. (2015) \\
\hline Top-down vs. Bottom-up & Lee et al. (2003) \\
\hline Systems vs. Techno-centric & Asif et al. (2010) \\
\hline Comprehensive vs. Selective (incremental) & Gil-Garcia et al. (2005) \\
\hline
\end{tabular}

Table 4. Information system integration degrees proposed in the literature

\begin{tabular}{l|l}
\hline Degrees of Integration & Author(s) \\
\hline Full (Total) - Partial integration - No integration & Asif et al. (2010) \\
& Giacomazzi et al. (1997) \\
\hline Tight integration - Loose integration & Themistocleous et al. (2004) \\
& Puschmann \& Alt (2001) \\
& Kalakota \& Robinson (1999) \\
& Helm (2000) \\
\hline Complete integration - Sparse integration & Brown (2000) \\
\hline Amalgamation - Cooperation - Harmonisation & Layne \& Lee (2001) \\
\hline
\end{tabular}

Considering the terms used to classify the degree of integration, similarity between the terms can easily be observed. But to what they refer varies with regard to the context. For example "complete" includes the use of the same domains such as (process, data, application etc.) whereas "total" ignores the organizational aspects of integration. Other terms such as amalgamation which may be associated with "complete" integration include organizational domain similarly. Therefore, all these terms can be summarized with a layered structure for the degree of integration as seen in Table 5.

Table 5. Layered degrees of integration

\begin{tabular}{c|c|c|c}
\hline Higher integration & \multicolumn{2}{c}{ Lower integration } \\
\hline Full integration & \multicolumn{2}{|c|}{ Partial integration } & No integration \\
\hline & Tight integration & Loose integration & \\
\hline Complete integration & \multicolumn{2}{|c|}{ Sparse integration } & \\
\hline Amalgamation & Cooperation & Harmonization & \\
\hline
\end{tabular}

\subsubsection{Levels of Integration}

As a close related term with the integration, interoperability was leveled under five titles: independent, ad hoc, collaborative, integrated and unified. Guédria et al. (2008) conducted a survey on interoperability maturity models. These models are main models that are used to represent interoperability measure and defined maturity levels within various interoperability environments. Levels of Information System Interoperability (LISI) are defined for 
information system interoperability to represent interoperability measure and to describe maturity levels. Moreover, organizational interoperability can be considered together with information system interoperability. Serving this purpose, Organizational Interoperability Maturity Model (OIM) defines interoperability at organizational level. They claim that since OIM covers business functions and technical interoperability is needed too, OIM should be used together with LISI. According to the International Organization for Standardization (ISO), there are three ways to develop interoperability: integrated (standard format for all constituent systems), unified (common meta-level) and federated (dynamically accommodated not a predetermined meta-model). According to Enterprise Interoperability Framework, levels were classified as interoperable, connectable, executable, initial and isolated. Some other researches denoted the levels as interoperable, interworkable, interconnectable, coexistent and incompatible.

The terms employed by many researchers in their studies to level the integration status show a similar pattern. In other words, levels can be matched with each other, For example, "universal" and "unified" from different classification proposed by the researchers indicate a comprehensive integration involving shared understanding. As a result, depending on the scope of the integration (or interoperability) appropriate maturity model can be used for the overall interoperability measurement of the studied systems. Guédria et al. (2008)'s comparison and categorization might be helpful to determine the appropriate models.

Levels suggested by different studies proposed might be matched and structured to express same or similar meanings based on the research of Guédria et al. (2008) as in Table 6.

Table 6. Information system integration levels proposed in the literature

\begin{tabular}{l|l|l|l|l|l}
\hline Author(s) & \multicolumn{5}{|c}{ Levels of Integration } \\
\hline $\begin{array}{l}\text { Guédria et al. } \\
(2008)\end{array}$ & Universal & Integrated & Distributed & Peer-to-peer & Manual \\
\hline Pankowska (2008) & Unified & Integrated & Collaborative & Ad hoc & Independent \\
\hline Chen et al. (2008) & Interoperable & Connectable & Executable & Initial & Isolated \\
\hline Izza (2009) & Interoperable & Interworkable & Interconnectable & Coexistent & Incompatible \\
\hline
\end{tabular}

\subsubsection{Measurement of IIS}

Based on the integration configuration, accurate measures are required for the parties of the integration to find out how successful they manage the process and how effective the integration is. This will help them clearly determine the critical points along the integration process. However insufficient, as implied by some researchers, there is a bunch of researches conducted on the topic of "integration measurement".

The assessment of IIS is important to realize the return on investment in IS integration (Petter et al., 2008). Petter and his colleagues tried to establish significant criteria and factors for successful IIS. They listed all the possible factors and criteria, and measurement items based on literature review and collected under four domains: physical and logical (denoted as technical in the study of Petter et al., 2008), organizational, and strategic. The details are given in Table 7, Table 8, Table 9, and Table 10 respectively. 
Table 7. Detail IIS success criteria in physical domain

\begin{tabular}{ll}
\hline Main Criteria & Measurement Items \\
\hline 1-Systems Quality & $\begin{array}{l}\text { Fast response time, fast turnaround time for any process, system reliability, } \\
\text { system completeness in meeting its integration and technical requirement, } \\
\text { system flexibility, system functionality }\end{array}$ \\
\hline 2-Information Quality & $\begin{array}{l}\text { The information format is according to the user needs and requirements, } \\
\text { system documentation quality, data quality, user interface consistency }\end{array}$ \\
\hline
\end{tabular}

(adopted from Petter et al., 2008)

Table 8. Detail IIS success criteria in logical domain

\begin{tabular}{ll}
\hline \multicolumn{1}{c}{ Main Criteria } & \multicolumn{1}{c}{ Measurement Items } \\
\hline 1-Integrated Systems & It integrates all information required by systems' owners and users \\
2-Integrated Business Process & It integrates all business (work) process of the organisation \\
\hline
\end{tabular}

(adopted from Petter et al., 2008)

Table 9. Detail IIS success criteria in organizational domain

\begin{tabular}{l|l}
\hline Main Criteria & Measurement Items \\
\hline 1-Service Quality & Service availability, reliability of service \\
\hline 2-Use & $\begin{array}{l}\text { Positive system use measured through identifying the user's nature of use and by } \\
\text { number of time (frequency) the system being used (visit/hit per day), number of } \\
\text { transactions increased or meet expected target }\end{array}$ \\
\hline 3- User Satisfaction & $\begin{array}{l}\text { User satisfaction based on project satisfaction, information satisfaction, } \\
\text { confidence in the system, repeat usage }\end{array}$ \\
\hline 4-Net benefit & $\begin{array}{l}\text { Overall profitability, productivity improvement, cost effective, improved } \\
\text { customer service, innovation capabilities, organizational flexibility, minimized } \\
\text { culture conflict, desired business process, improved business process, optimized } \\
\text { system cost, reduced cycle time, enhanced decision making, undesired political } \\
\text { behavior and power game is minimized }\end{array}$ \\
\hline
\end{tabular}

(adopted from Petter et al., 2008)

Table 10. Detail ISS success criteria in strategic domain

\begin{tabular}{l|l}
\hline Main Factors & Measurement Items \\
\hline 1-Teamwork & $\begin{array}{l}\text { Project team shares all information regarding the project, consists of a mix of } \\
\text { business process experts and developers, and has a highly skill technical } \\
\text { members. The project team members have business and technical knowledge, } \\
\text { and regards the project as top priority and consider it manageable }\end{array}$ \\
\hline $\begin{array}{l}\text { 2-Change } \\
\text { Management Program } \\
\text { 3-Tulture }\end{array}$ & $\begin{array}{l}\text { Change management program that produce manageable culture and structural } \\
\text { change, develop strong commitment to integration effort, and provide training } \\
\text { re-skilling of staff based on the integration goal }\end{array}$ \\
$\begin{array}{l}\text { Support Management } \\
\text { 4-Strategic Plan \& } \\
\text { Vision }\end{array}$ & $\begin{array}{l}\text { Project approval, considering the project as top priority, aligning the project } \\
\text { with strategic business goal, personal involvement and supporting resources }\end{array}$ \\
\hline $\begin{array}{l}\text { 5-Business Process } \\
\text { Reengineering }\end{array}$ & $\begin{array}{l}\text { Quar business plan, clear operational model and plan and vision that tied } \\
\text { directly to business direction }\end{array}$ \\
\hline $\begin{array}{l}\text { 6- Project } \\
\text { Management }\end{array}$ & $\begin{array}{l}\text { Effective project management with established and controlled scope, clear } \\
\text { and limited agreed scope, and a coordinated training }\end{array}$ \\
\hline $\begin{array}{l}\text { 7-Effective } \\
\text { communication }\end{array}$ & $\begin{array}{l}\text { Make the project known to all, having communication channel at every } \\
\text { organisation level, ongoing project promotion and announcement }\end{array}$ \\
\hline $\begin{array}{l}\text { 8-Development, } \\
\text { Testing }\end{array}$ & $\begin{array}{l}\text { Problem solving capability in the development, testing and troubleshooting, } \\
\text { the use of proper tools and techniques. }\end{array}$ \\
\hline $\begin{array}{l}\text { 9-Project Champion } \\
\text { continually strive in resolving conflict and manage resistance }\end{array}$ \\
\hline
\end{tabular}


(adopted from Petter et al., 2008)

Measuring IS integration, Chapman \& Kihn (2009) found IS integration being correlated with the perceived performance. Moreover, Gillies et al. (1993) argues that the perceived integration is positively correlated with perceived effectiveness. Considering these studies together, integration can be claimed to have an indirect effect on firm's performance.

\subsection{Best Practices of IS in Municipalities}

New technology environment enforced municipalities to adopt IS and web-based systems in every citizen services provided. Furthermore, the more integrated these systems are, the more likely they meet citizens' expectations. In the light of latest status of IS in municipalities, majority of e-municipality research is conducted on either use and adaptation or design and analysis of these electronic systems. Factors affecting IS acceptance and usage is studied by many researchers (Dastan, 2015; Zeren, 2015; Seo \& Bernsen, 2016) through questionnaires and qualitative analyses. Various methods are used in the analysis of existing electronic government systems (Holzer \& Kim, 2003; Sandoval-Almazan et al., 2012; Yaman et al., 2013; Holzer et al, 2014). Moreover, IIS is one of the concerning topics in the analyses.

Holzer, in their longitudinal study conducted with different researchers, prepared a progressive report for the United Nations to assess digital governance efforts in 100 city municipalities in the world with population greater than 100,000 between 2003 and 2014 . The city and municipality websites were evaluated on five categories: 1 . Security and Privacy; 2. Usability; 3. Content; 4. Services; and 5. Citizen Participation. Assessing a score for each category on a scale between 0 and 20, a total score was calculated for each city. Seul from Republic of Korea was ranked first both in 2003 and 2014 with overall score of 73.48 and 85.80 respectively. As seen in Table 11, comparing the average category scores for top 20 cities in respective years, average category scores did not much progress in the last one decade. E-municipality initiatives need to focus more on improving the scores in all categories.

Table 11. Score values for privacy, usability, content, services and participation

\begin{tabular}{llrrrrrr}
\hline & & \multicolumn{1}{c}{ Overall } & \multicolumn{1}{c}{ Privacy } & Usability & \multicolumn{1}{c}{ Content } & \multicolumn{1}{c}{ Services } & Participation \\
\hline \multirow{2}{*}{2003} & Average & 49.25285 & 7.1256 & 15.32965 & 11.23335 & 8.8874 & 6.6794 \\
& Minimum & 37.28 & 0 & 10.94 & 7.66 & 5.439 & 2.56 \\
& Maximum & 73.48 & 15.36 & 19.38 & 14.68 & 15.44 & 15.64 \\
\hline \multirow{2}{*}{2014} & Average & 55.8615 & 10.5185 & 14.9345 & 12.2875 & 10.78 & 7.345 \\
& Minimum & 45.36 & 3.7 & 11.57 & 7.94 & 5.9 & 2.92 \\
& Maximum & 85.8 & 16.3 & 17.82 & 17.46 & 16.72 & 18.75 \\
\hline
\end{tabular}

(adopted from Holzer \& Kim, 2003 and Holzer et al., 2014)

Measurement of IIS, discussed in section 2.1.5, gives insight about the integration state of the systems. Likewise, most of the research, based on the same approach, measures the integration level of IS by investigating available e-municipality services which are accessible through their web pages.

D'Agostino et al. (2011) examined public sector's existing service capability of e-government applications through websites. Examination is conducted on 20 most populated cities in the 
U.S. Two researchers have scored the selected web sites according to the evaluation index which is a derivation of Holzer and Kim's (2003) e-governance performance index with forty new measures. According to the scores, some differences are found between high scored and low scored municipalities such as having online licensing, property assessment services and ability to track permits services. At the end of the evaluation, they reasoned the aforementioned difference with several interpretations. First of all e-government integration is applied for being more effective, so that eliminating duplicative services gained more attraction than producing new services. This orientation affected the number of e-government services currently provided. Secondly, paucity of citizen participation in municipal administration is effected the use rate of e-government services in general.

Susceptibility of Aydin citizens to participate in e-municipality services is measured and evaluated through a questionnaire by Zeren et al. (2015). At the end of the study citizens are found to be willing, however various reasons prevent them from actively participating like having doubt on trusting the security of internet operations including e-government services. At least $50 \%$ of the participants have no opinion on trustworthiness of using internet for e-banking, e-trading and e-government operations. Besides the main research question, a difference between city/metropolis and county municipalities is observed. While metropolis municipality has, not all of the county municipalities have electronic municipality applications; even some of them are under maintenance.

Yaman et al. (2013) conducted a content analysis on municipality websites in Black Sea Region of Turkey. The aim is scanning and comparing e-municipality applications available through the municipality websites. They determined 10 different major topics and several services under each topic, and then websites are graded according to existence of these services. At the end total scores are calculated and used in the comparison of municipalities. Finally suggestions are provided to increase the service quality in e-municipality services. Major topics and services provided by Yaman et al. (2013) can be used in new content analysis studies as a reference.

Conducting site visits in Mexico, Sandoval-Almazan et al. (2012) argues that municipal internet portals are still mainly used for information displaying purposes. In that study, opportunities to promote interaction and participation of citizens in city governance through web portals are outlined, and incorporation of necessary channels into local government portals is proposed.

Cegarra-Navarro et al. (2012) investigated use of municipality websites at 179 Spanish towns. The results suggested that information and communication technology (ICT) allows more people to get benefit from e-government services and in turn this improves civic engagement of citizens. However, successful implementation of ICT strictly depends on the adoption of e-government services by government officers.

\section{Methodology}

The aim of the study is to analyze implementation and effectiveness of e-government at the municipal level in the vision of IS integration and to propose a roadmap for an integrated 
municipal IS from citizen's perspective. For this purpose, the citizen services, strategies, and organizational and IT structures of several municipalities are examined and analyzed from different IIS perspectives. The methodology consists of two phases which are interviewing and an investigation.

In Phase I, a meeting is held with the municipal advisor, communication and media coordinator, and IT manager of the municipality Sariyer of Istanbul city in order to provide information about the study, to get opinions of administrative personnel about the IIS and to set up interviews with related departments. Taking the recommendations of the first meeting into account, the responsibilities, action plans and activity report of a municipality are examined and a list of questions is prepared in order to obtain information about the current IS, stakeholders, information sharing with stakeholders, and required modules of the IS. An interview is conducted with IT department manager and officers based on this list and associated literature. Detailed system information is obtained with additional questions during the interview

In Phase II, an investigation study is conducted to specify the existence and types of online citizen services of municipalities via municipality websites. Purposive sampling technique is applied for this investigation study. First, cities with the highest population from each seven geographic region in Turkey are selected. Then, one municipality for each city is selected for investigation in the study according to number of web service functionalities. These regions, cities and municipalities are shown on Table 12.

Table 12. The samples of the investigation study

\begin{tabular}{lll}
\hline Region & City & Municipality \\
\hline Aegean Region & İzmir & Menderes \\
Black Sea Region & Samsun & Bafra \\
Central Anatolia Region & Ankara & Keçiören \\
Eastern Anatolia Region & Van & Edremit \\
Marmara Region & İstanbul & Sariyer \\
Mediterranean Region & Adana & Seyhan \\
Southeastern Region & Gaziantep & Şahinbey \\
\hline
\end{tabular}

\section{Results, Analysis and Findings}

After the structured interview (Phase I) conducted with Saryer Municipality, the current implementation of IS architecture was investigated in the organization. Initially, the first dimension (domain) defining the areas where integration occurs as strategic, organizational, logical and physical site is examined. Sariyer Municipality had problems with their previous IS infrastructure because of vendor support and therefore changed their infrastructure with a new system in 2012. The municipality combined management information system, electronic document management system, geographic information systems, business intelligence and in-house portals in a single platform "DIGIKENT" for increasing the quality of services provided, facilitating the service delivery, and providing a more smooth and rapid progress of business processes.

The municipality IS has modules and each module contains its own data infrastructure. However common database is used for online services provided by "e-municipality" 
application and the usage of this database is based on authentication. When a real estate is purchased in municipality territory or a new baby is born, the municipality needs to reach the newcomer's identity. Identity information of citizens is queried via e-government web services through e-municipality application when needed. There are manual systems for some citizen services; for example, ambulance requests and follow-up are done via call center. In addition, some citizen services like weddings processes and store licensing cannot be operated online although these systems are ready for the integration. Some systems including inspection services information system and banner tracking system are under construction. On the other hand, they do not have any system for managing health information such as health examination information, drug help information, laboratory test results; and common public education information like course participation status.

While integration occurred at physical and logical domains, there are no integrations at strategic and organizational domains. They aim to make integration at strategic and organizational domains after moving to the new municipality building. The corporate governance structure of the municipality consists of 28 directorships. Directorships is under the responsibility of Vice-Presidents with respect to Vice-Presidents' competencies. There is a document official in each directorate and information sharing between them is in the context of legislation and through editorial office. On the other hand, there is information sharing between external stakeholders which are official institutions like directorate of land registry, directorate of civil registration and organizations and the scientific and technological research council of Turkey (TÜBİTAK); private institutions and organizations (eg. banks), professional organisations with public institution status, civil society organizations, national address database. There is no physical contact with the external stakeholder neighborhoods but the municipality intends to extent the current system for neighborhood management.

Considering the second dimension (approach), the structure of the integration is determined to be centralized since IT department initiates the municipality services. Furthermore, the extent of the integration is internal, because this process is only active inside of Saryer Municipality, and no third parties are involved. Additionally, the direction of integration is horizontal, as integration process is service-oriented for citizens. Lastly, the hierarchy of the integration is generally speaking top-down where management decides the citizen services to be delivered online through requests from the citizens and other stakeholders are taken into consideration as well. It should be noted that one of the reasons behind this top-down approach is resistance from users of the IS. In order to break that resistance a corporate top management decision might be necessary. In contrast, for the strategic domain a bottom-up approach is adopted which is in line with the citizen-based view. Applying this approach gives citizens opportunity to propose their demands and suggestions directly. Public discussions with citizens are held in order to gather suggestions and build strategic roadmap. After all, current IS is flexible enough to meet existing and future expectations of stakeholders.

The third dimension (degree) defining the strictness of unification is examined in terms of domains: fully integrated at physical domain, partially integrated at logical domain and no integration at organization and strategic domains. Sariyer Municipality uses single platform for all services and internal processes as stated before. This indicates that the system is fully 


\section{Macrothink}

integrated at physical domain. During the interview and analysis of the web-based services, it is found out that there are some internal processes that have not been implemented into the main system yet. The reason is not the technical barriers but mostly current workload because of ongoing projects and organizational barriers. For instance, the library management system is under the control of Department of Culture and Social Affairs. Furthermore, current system users show resistance against development of a new software module in the central IS. On the other hand, most of the services are integrated and there is no manual process during information transfer. This shows that there is partial integration at logical level. At organization and strategic domain, integration status is examined as no integration. As mentioned before, after moving to the new municipality building, some departments are going to be merged. Therefore, it is inferred that partial integration is aimed at organization domain. For strategic integration there is no deadline aimed or stated during the interview.

Last dimension (level) of integration conceptualizes the overall integration of the project into levels namely as the universal, integrated, distributed, peer-to-peer and manual. According to this definition, Municipality of Sarıyer can be considered as universal since there is a standard for all constituent systems even though not all services are provided with single software and the municipality has a central data repository where data is fully shared and distributed between all organizational units.

Based on the investigation study (Phase II) of seven municipalities in Turkey, the summary of web-based citizen services are presented in Table 13 and grouped under the titles based on the service fields of municipalities.

According to these two studies mentioned in Phase I and II, it can be stated that there should be 22 subsystems and these subsystems should have interrelationships between themselves in terms of citizen services. These subsystems and their dependencies are outlined by the package diagram given in Figure 1. 
Table 13. The municipalities and citizen web services

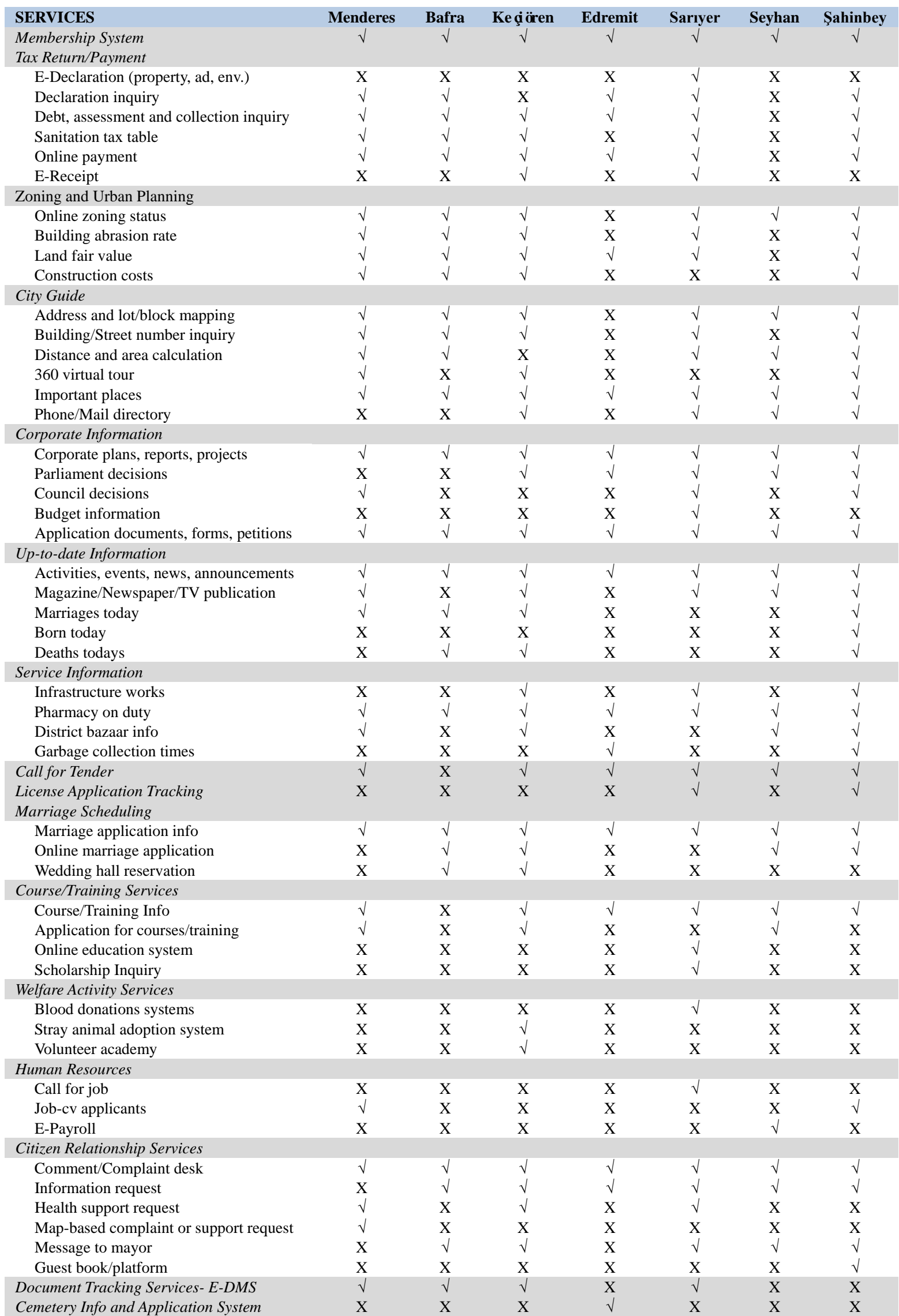




\section{Macrothink}

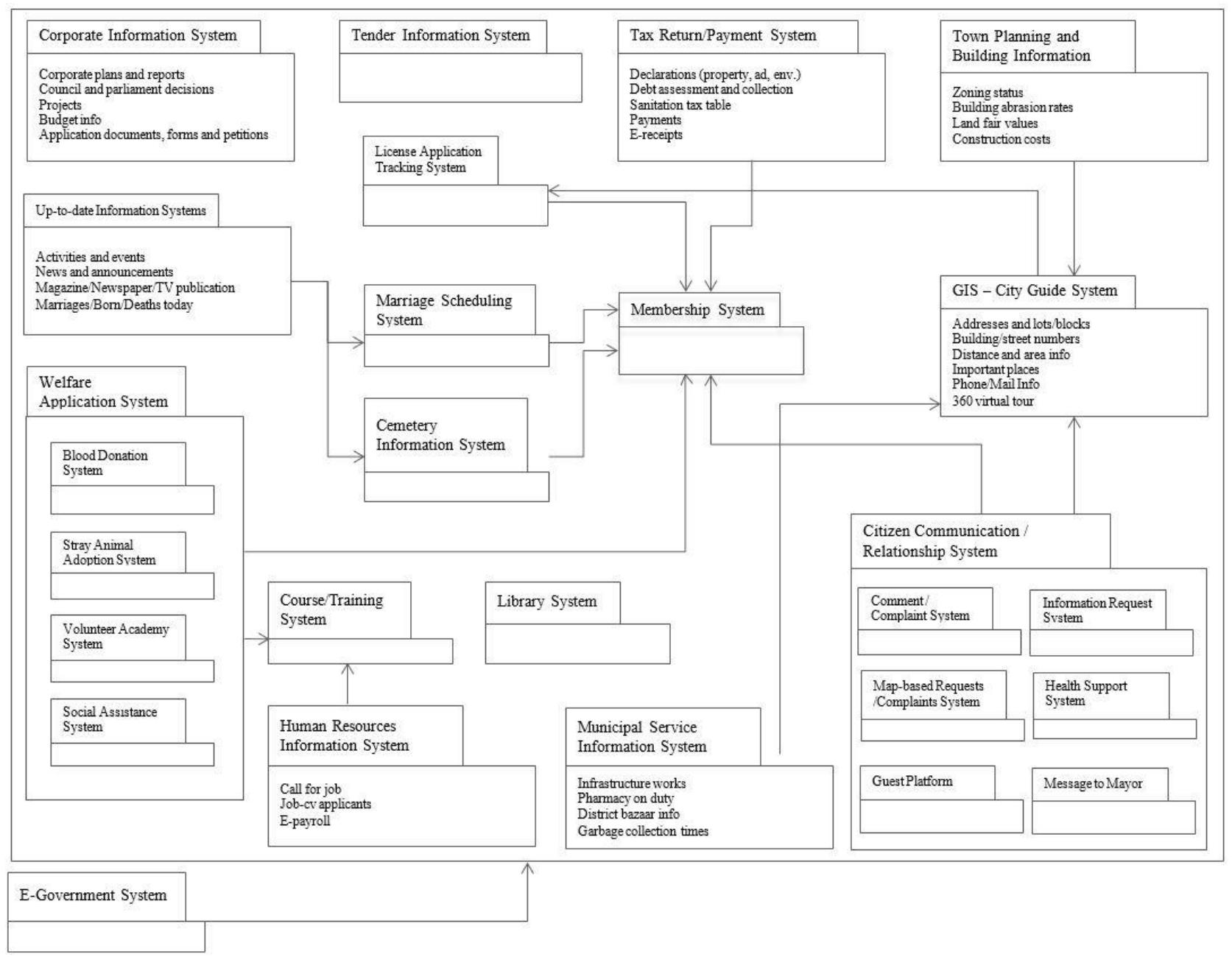

Figure 1. The Package Diagram of the Proposed Municipal IIS

\section{Recommendation}

Municipalities are dynamic institutions such that organizational strategies might need to be updated as new situations arise, and therefore, IS strategy decisions have to be in line with organizational strategy to prevent potential technological pitfalls. However, IS investments in public institutions are usually expensive and target great number of users, and this requires IS strategy decisions at municipalities to be long-term plans as much as possible to have maximum cost savings and highest level of customer experience. At this point, existence of a coordination unit might help ensuring the perfect alignment of IS strategy at strategic, organizational, physical and logical domains.

\subsection{Strategic Domain}

At strategic domain, internal and bottom-up approaches should be adopted. Internal approach is recommended because each municipality provides services only to its own citizens, and external entities do not have direct interactions with citizens. Since IIS is proposed from the citizen services point of view, it is expected to have citizens as starting point at any strategy related decisions. This can be achieved only through adoption of a bottom-up approach at strategic domain. Appropriate degree of integration at the strategic domain is full integration, 
but this can be achieved through only existence of a coordination unit.

Coordination unit is recommended unless it has the responsibility for alignment of IS strategy and assigned for a role of IIS success. Initial step starts with definitions of vision and mission that best meets citizens' requirements and future expectations. This unit should include highly skilled people that have deep business and technical knowledge who operationalize strategic specifications into performance goals for each department. Additionally, this unit must be part of project team during integration phase and continue its responsibilities after project implementation in order to control alignment of citizen services with strategic goals. Top management should support both the project and the coordination unit. Coordination unit should establish a communication channel between project team, staff and top management. This unit should also take responsibility during change management program and train staff about the innovations with new IS and changes in business processes that affect citizens. During development and testing phase, members of the unit should control the new system in terms of citizen's needs, benefits, and overall satisfaction.

\subsection{Organizational Domain}

Integration in organizational domain plays a significant role in integration of citizen service information systems. Internal and horizontal approaches should be followed at organizational domain. Requirement of internal approach depends on scope of provided IIS services which are limited to the internal organization of the municipality. Horizontal approach suggests integration between functions which are served by different organizational units within the municipality but serve for the same municipality function. As in the strategic domain, full integration is recommended in the organizational domain as well. However for monetary decisions affecting budget of the municipality, horizontal approach might need to be broken because of legal obligations.

IISs are considered successful in organizational domain extent to which they can fulfill the criteria namely as service quality, use, user satisfaction and net benefit, as proposed by Petter et al. (2008). The recommendations can be made in accordance with these criteria.

Service quality is "the quality of the support that system user receive from the IS department and IT support personnel" (Petter et al., 2008). Service availability and reliability are the items of service quality to be included in the measurement process. Related to the study, it is urgent for municipalities to provide the citizens with reliable and available service whenever it is needed. The improvement in these fields can be tracked by feedbacks which are collected from the website or surveys conducted periodically to the citizens. SERVQUAL, a 22-item instrument developed by Parasuraman et al. (1988) can be adapted to assess the citizen's perception towards service quality.

In addition, system use and user satisfaction are other important success criteria for organizational integration of IS. While system use can be measured by usage frequency (visit / hit per day) or number of transactions, user satisfaction bases on project satisfaction, information satisfaction, confidence in the system and repeat usage according to Petter et al. (2008). For these criteria, top management support can be recommended. Top management 
support positively influences perceived usefulness and user satisfaction (Al-Mamary et al., 2014). It tries to encourage the use of system and ensure the pleasure of the users (Igbaria et al., 1997). Therefore, municipalities should provide the necessary support for system using and awareness of the benefits of system using.

The last criteria which should be carefully satisfied is net benefit which indicates the extent to importance of IS on the success of organizations. When taking a closer look at the net benefit measurement items (Petter et al., 2008), it is obvious that lots of tangible measures such as overall profitability, productivity improvement, and reduced cycle time are involved. Improvements in the values of these items are the results of a successful integration and more easy to observe through the transactional data, thus enhancing the decision making. On the other hand, the other items such as organizational flexibility, minimized culture conflict or minimization of undesired political behavior and power game highlight the cooperation and harmonization across the corporation. From a citizen-centric view, among all items, municipalities should especially chase reduction in cycle time and improvement in the citizen services by storing, processing and disseminating the transactional data through a successful information system. The other items should be handled within the municipality organization and must contribute to the improvements in the ones which are directly related to citizen satisfaction.

\subsection{Logical Domain}

At logical domain internal and centralized approaches should be applied. There is no need for integration among distinct municipalities at logical domain. Centralized approach is appropriate for this domain because all operations share a common logical base such as citizen data is common for all services. Similarly to degree of integration in previous two domains, full integration is recommended for logical domain. Since integration at this domain depends on technology mostly, rigidity is easier to obtain and will gain effectiveness.

Two criteria are determined to measure success of an IIS in logical domain by Petter et al. (2008). Integrated systems criteria, requires integration of all information provided and used by system's owners and users. A citizen-centric view of IIS in municipalities offers citizen information at the center of all information produced by all related services. Therefore, data model and entity relationship design should be planned by placing the citizen data at the center. Besides, designing related data tables/models in the same database will ease data access of the system for multiple service functions. This united approach for the logical domain is an implementation of suggested centralized approach. The second criterion is integrated business process which applies integration of all business processes of the organization. A municipality IIS will be successful according to this criterion if business processes related to citizen services are integrated well. An opposite scenario is having separate software systems managed by different departments in the municipality. Separate systems should be managed by the same department, besides flow of their business processes should be designed in coordination with each other. This coordinated approach includes planning of data exchange and coordination between different services and business units. 


\subsection{Physical Domain}

Physical integration needs to be dimensionally external and hierarchically top-down process. This is because no system is totally isolated from the external environment, therefore Wide Area Network, Virtual Private Network or the Internet connection is needed. Since physical connection is not feasible to provide eventually or when required, a central plan and topology should be defined before actual operation, requiring a top-down initiative.

Target value for network connectivity should be determined and it should be raised as much as possible to reach to that target. Every integration process need not result in star topology (every node is connected to others), however target network connectivity should be especially high for cases requiring high cooperation and coordination in terms of IT operations.

Response time is another important metric for physical interoperability. It should be measured specifically when the network is under heavy workload, in order to have a worst-case scenario. Once target response time is determined for the network, achieving it might require a network structure change. For instance, if a low response time is critical between two units, removal of network devices such as switches and hubs, and lowering physical distance between the two units, might be needed.

For data quality and usefulness, questionnaires on satisfaction of data supplied should be implemented to users. Logs of system breakdown should be kept and carefully examined. User roles and rights should be determined according to needs-to-know basis so that data and information could be protected from unauthorized operation. Data access logs should be checked on a regular basis as well.

\section{Conclusion}

Today, technology is key element for any business in providing prompt and reliable service to customers and local governments are not an exception. With the rapid advances in information technology, there has been a growing interest in development of e-municipality platforms among local governments over the last decade. While it is possible only through these platforms to have better communication and interaction among different organizational units inside a local government, e-municipality platforms provide citizens with unique opportunity to receive prompt service and seamless experience as well.

Due to the complex relationships among stakeholders, e-municipality systems require to be built upon a well-designed integrated information systems roadmap. Local governments have interactions with many other internal and external entities, and therefore it is recommended to define the scope of a roadmap carefully for parsimony reasons. In this study, development of an IIS roadmap for local governments is developed and discussed from citizen services perspective.

Based on the existing literature and interviews conducted at a local government (Sariyer) in Istanbul and, an IIS framework similar to the one suggested by Madnick \& Wang (1988) is developed. Basically, IIS for local government is considered at four domains: strategic, organizational, logical, and physical. 
Initially, a preliminary investigation in local governments in Turkey is conducted. One municipality from each of seven geographical regions is selected, analyzed and compared in terms of current integration status and provided online citizen services. A framework is outlined to cover all online services offered by any local government. As a result of these observations, a practical model based on the theory and framework is developed and it is demonstrated on a package diagram. At the end, the new model including recommendations at domain level is discussed with IT department at municipality of Sarlyer. The suggested model and integration roadmap are found to be in line with current practices and existing strategic plan of the municipality. Therefore, their support and approval on the suggested model are obtained as well.

At strategic domain, internal and bottom-up approaches with full integration are recommended, and also a coordination unit might be helpful in aligning the stakeholders with the strategy as needed. Internal and horizontal approaches with full integration should be applied at organizational domain. However, at this domain, a certain level of vertical approach might still be needed due to legal issues. At logical domain, internal and centralized approaches with full integration are recommended. External and top-down approaches should be applied at physical domain.

As future work, a similar roadmap can be developed at a broader level such as metropolitan municipalities or state governments. In addition, software companies can take this roadmap into account while building information systems for local governments.

\section{References}

Al-Mamary, Y. H., Shamsuddin, A., \& Aziati, N. (2014). Factors affecting successful adoption of management information systems in organizations towards enhancing organizational performance. American Journal of Systems and Software, 2(5), 121-126.

Almarabeh, T., \& AbuAli, A. (2010). A general framework for e-government: definition maturity challenges, opportunities, and success. European Journal of Scientific Research, 39(1), 29-42.

Asif, M., de Bruijn, E. J., Fisscher, O. A., Searcy, C., \& Steenhuis, H. J. (2009). Process embedded design of integrated management systems. International Journal of Quality \& Reliability Management, 26(3), 261-282. https://doi.org/10.1108/02656710910936735

Asif, M., Fisscher, O. A., de Bruijn, E. J., \& Pagell, M. (2010). An examination of strategies employed for the integration of management systems. The TQM Journal, 22(6), 648-669. https://doi.org/10.1108/17542731011085320

Beckmerhagen, I., Berg, H., Karapetrovic, S., \& Willborn, W. (2003). Integration of management systems: focus on safety in the nuclear industry. International Journal of Quality \& $\quad$ Reliability 20(2), 210-228. https://doi.org/10.1108/02656710310456626

Bekkers, V. (2009). Flexible information infrastructures in Dutch E-Government collaboration arrangements: Experiences and policy implications. Government Information 
Quarterly, 26(1), 60-68. https://doi.org/10.1016/j.giq.2007.09.010

Bernardo, M., Casadesus, M., Karapetrovic, S., \& Heras, I. (2008). Management systems: integration degrees. Empirical study. Paper presented at the 11th QMOD Conference. Quality Management and Organizational Development Attaining Sustainability from Organizational Excellence to Sustainable Excellence; 20-22 August; 2008 in Helsingborg; Sweden.

Bhatt, G. D., \& Troutt, M. D. (2005). Examining the relationship between business process improvement initiatives, information systems integration and customer focus: an empirical study. Business Process Management Journal, 11(5), 532-558. https://doi.org/10.1108/14637150510619876

Brown, L. (2000). Integration models: templates for business transformation: Sams.

Cegarra, N. J. G., Pachón, J. R. C., \& Cegarra, J. L. M. (2012). E-government and citizen's engagement with local affairs through e-websites: The case of Spanish municipalities. International Journal of Information Management, 32(5), 469-478. https://doi.org/10.1016/j.ijinfomgt.2012.02.008

Chapman, C. S., \& Kihn, L. A. (2009). Information system integration, enabling control and performance. Accounting, organizations and society, 34(2), 151-169. https://doi.org/10.1016/j.aos.2008.07.003

Chen, D., Doumeingts, G., \& Vernadat, F. (2008). Architectures for enterprise integration and interoperability: Past, present and future. Computers in industry, 59(7), 647-659. https://doi.org/10.1016/j.compind.2007.12.016

D'agostino, M. J., Schwester, R., Carrizales, T., \& Melitski, J. (2011). A study of e-government and e-governance: An empirical examination of municipal websites. Public Administration Quarterly, 35(1), 3-25.

Evgeniou, T. (2002). Information integration and information strategies for adaptive enterprises. European Management Journal, 20(5), 486-494. https://doi.org/10.1016/S0263-2373(02)00092-0

Giacomazzi, F., Panella, C., Pernici, B., \& Sansoni, M. (1997). Information systems integration in mergers and acquisitions: A normative model. Information \& management, 32(6), 289-302. https://doi.org/10.1016/S0378-7206(97)00031-1

Gil, G, J. R., Schneider, C. A., Pardo, T. A., \& Cresswell, A. M. (2005, January). Interorganizational information integration in the criminal justice enterprise: Preliminary lessons from state and county initiatives. Paper presented at the System Sciences, 2005. HICSS'05. Proceedings of the 38th Annual Hawaii International Conference on. USA: IEEE. https://doi.org/10.1109/HICSS.2005.338

Gillies, R. R., Shortell, S. M., Anderson, D. A., Mitchell, J. B., \& Morgan, K. L. (1993). Conceptualizing and measuring integration: findings from the health systems integration study. Journal of Healthcare Management, 38(4), 467. 
Guédria, W., Naudet, Y., \& Chen, D. (2008, November). Interoperability Maturity Models-Survey and Comparison-. In On the move to meaningful Internet systems: OTM 2008 Workshops (pp. 273-282). Springer Berlin Heidelberg.

Heeks, R. (1999). Reinventing government in the information age: International practice in IT-enabled public sector reform, $1 . \quad$ Psychology Press. https://doi.org/10.4324/9780203204962

Helm, R. (2000). Extending EAI beyond the enterprise. EAI journal.

Henderson, J. C., \& Venkatraman, H. (1993). Strategic alignment: Leveraging information technology for transforming organizations. IBM systems journal, 32(1), 472-484. https://doi.org/10.1147/sj.382.0472

Holzer, M., \& Kim, S. (2003). Digital governance in municipalities worldwide: An assessment of municipal web sites throughout the world-2003. Newark: National Center for Public Performance. ISBN, 942942035.

Holzer, M., \& Manoharan, A. (2014). Digital governance in municipalities worldwide (2013-14) sixth global e-governance survey: A longitudinal assessment of municipal websites throughout the world. National Center for Public Performance School of Public Affairs and Administration, Rutgers University-Newark, 2015-16.

Hugoson, M. Å. (2007). Centralized versus Decentralized Information Systems. Paper presented at the IFIP Conference on History of Nordic Computing.

Igbaria, M., Zinatelli, N., Cragg, P., \& Cavaye, A. L. (1997). Personal computing acceptance factors in small firms: a structural equation model. MIS quarterly, 279-305. https://doi.org/10.2307/249498

Izza, S. (2009). Integration of industrial information systems: from syntactic to semantic integration approaches. Enterprise Information Systems, 3(1), 1-57. https://doi.org/10.1080/17517570802521163

Jørgensen, T. H. (2008). Towards more sustainable management systems: through life cycle management and integration. Journal of cleaner production, 16(10), 1071-1080. https://doi.org/10.1016/j.jclepro.2007.06.006

Kalakota, R., \& Robinson, M. (1999). e-business: Roadmap for Success. Boston: Addison Wesley.

Layne, K., \& Lee, J. (2001). Developing fully functional E-government: A four stage model. Government information quarterly, 18(2), 122-136.

https://doi.org/10.1016/S0740-624X(01)00066-1

Lee, J., Siau, K., \& Hong, S. (2003). Enterprise Integration with ERP and EAI. Communications of the ACM, 46(2), 54-60. https://doi.org/10.1145/606272.606273

Madnick, S. E., \& Wang, Y. R. (1988). A framework of composite information systems for strategic advantage. In System Sciences, 1988. Vol. III. Decision Support and Knowledge 
Based Systems Track, Proceedings of the Twenty-First Annual Hawaii International Conference on, 3, 35-43. IEEE. https://doi.org/10.1109/HICSS.1988.11886

Maiga, A. S., Nilsson, A., \& Ax, C. (2015). Relationships between internal and external information systems integration, cost and quality performance, and firm profitability. International Journal of Production Economics, 169, 422-434. ttps://doi.org/10.1016/j.ijpe.2015.08.030

Moon, M. J. (2002). The evolution of e - government among municipalities: rhetoric or reality? Public administration review, 62(4), 424-433. https://doi.org/10.1111/0033-3352.00196

Panetto, H., \& Cecil, J. (2012). Information systems for enterprise integration, interoperability and networking: theory and applications. Enterprise IS, 1-6.

Pankowska, M. (2008). National frameworks' survey on standardization of e-Government documents and processes for interoperability. Journal of theoretical and applied electronic commerce research, 3(3), 64-82.

Parasuraman, A., Zeithaml, V. A., \& Berry, L. L. (1988). Servqual: A multiple-item scale for measuring consumer perc. Journal of retailing, 64(1), 12.

Peterson, R. R. (2004). Integration strategies and tactics for information technology governance. Strategies for information technology governance, 2, 37-80. https://doi.org/10.4018/978-1-59140-140-7.ch002

Peterson, R. R., O'Callaghan, R., \& Ribbers, P. (2000, December). Information technology governance by design: investigating hybrid configurations and integration mechanisms. In Proceedings of the twenty first international conference on Information systems (pp. 435-452). Association for Information Systems.

Petter, S., DeLone, W., \& McLean, E. (2008). Measuring information systems success: models, dimensions, measures, and interrelationships. European journal of information systems, 17(3), 236-263. https://doi.org/10.1057/ejis.2008.15

Platts, K. (1995). Integrated manufacturing: a strategic approach. Integrated Manufacturing Systems, 6(3), 18-23. https://doi.org/10.1108/09576069510086107

Puschmann, T., \& Alt, R. (2001, January). Enterprise application integration-the case of the Robert Bosch Group. In System Sciences, 2001. Proceedings of the 34th Annual Hawaii International Conference on (pp. 10-pp). IEEE. https://doi.org/10.1109/HICSS.2001.927242

Sandoval, A. R., \& Gil, G. J. R. (2012). Are government internet portals evolving towards more interaction, participation, and collaboration? Revisiting the rhetoric of e-government among municipalities. Government Information Quarterly, 29, S72-S81. https://doi.org/10.1016/j.giq.2011.09.004

Seo, D., \& Bernsen, M. (2016). Comparing attitudes toward e-government of non-users versus users in a rural and urban municipality. Government Information Quarterly, 33(2), 
270-282. https://doi.org/10.1016/j.giq.2016.02.002

Shea, C. M., \& Garson, G. D. (2010). Handbook of public information systems: CRC Press.

Themistocleous, M., Irani, Z., \& Love, P. E. (2004). Evaluating the integration of supply chain information systems: A case study. European Journal of Operational Research, 159(2), 393-405. https://doi.org/10.1016/j.ejor.2003.08.023

Wyse, J. E., \& Higgins, C. A. (1993). MIS integration: a framework for management. Journal of Systems Management, 44(2), 32.

Yaman, K., Asgin, S., \& Kaya, A. G. E. (2013). Comparative analysis of the e-municipality applications in Turkey: The case of western black sea region. Yönetim ve Ekonomi, 20(1), 207-220.

Zeren, H. E., Sebetçi, O., \& Koçak, Y. (2015). E-devlet ve e-belediye hizmetleri çerçevesinde aydin halkinin katilma duyarliliginin ölçülmesi. Kafkas University. Faculty of Economics and Administrative Sciences. Journal, 6(9), 249.

\section{Copyright Disclaimer}

Copyright for this article is retained by the author(s), with first publication rights granted to the journal.

This is an open-access article distributed under the terms and conditions of the Creative Commons Attribution license (http://creativecommons.org/licenses/by/4.0/). 